\title{
ЕФЕКТИВНІСТЬ ЗАСТОСУВАННЯ ЕНЕРГО-ПРОТЕЇНОВИХ ДОБАВОК ІЗ ЗАХИЩЕНИМ ПРОТЕЇНОМ ПРИ ВИРОЩУВАННІ РЕМОНТНИХ ТЕЛИЦЬ
}

\author{
Сєдюк Ігор Євгенович \\ кандидат сільськогосподарських наук \\ Інститут тваринництва НААНУ \\ ORCID: 0000-0003-1765-2868 \\ E-mail: sedyuk57@mail.ru
}

Золотарьов Андрій Петрович науковий співробітник Інститут тваринництва НААН ORCID: 0000-0001-8571-3840 E-mail: apz_2013@ukr.net

Золотарьова Світлана Анатоліївна кандидат сільськогосподарських наук Харківський Національний аграрний університет ORCID: 0000-0001-7275-5603

E-mail: szoloto549@ gmail.com

Машкін Микола Іванович кандидат сільськогосподарських наук, профеесор Сумський національний аграрний університет ORCID: 0000-0003-4585-4029 E-mail: kalin42@ukr.net

У статті наведені результати дослідження з визначення ефективності використання в годівлі ремонтних телиць розроблених енерго-протеїнових добавок з захищеним від розщеплення в рубці протеїном на 62 65\% при вирощуванні ремонтних телиць з після молочного періоду до запліднення у порівнянні з традиційними білковими добавками - соняшниковим та соєвим шротами. Кормові добавки ТЕП-мікс і КЕБ розроблені спільно співробітниками Інституту тваринництва НААН та ТОВ «Арніка ФІД» (м. Глобине Полтавської області). Науково-господарські дослідження проводили на базі ДП ДГ «Гонтарівка» Інституту тваринництва НААН. У досліді тривалістю 487 днів на чотирьох групах молодняку молочного напрямку продуктивності по 12 голів у кожній вивчали фактичне споживання кормів, визначали динаміку живої маси, середньодобові прирости, термін першого приходу в охоту, першого осіменіння та запліднення. Доведено позитивний вплив використання розроблених енерго-протеїнових добавок з захищеним протеїном ТЕП-мікс і КЕБ в годівлі ремонтних телиць з післямолочного періоду. Введення до складу раціону ремонтного молодняку молочного напрямку продуктивності добавки ТЕП-мікс дозволило отримати середньодобові прирості за весь період вирощування на 4,53 \% більші у порівнянні з використанням в раціонах шроту соняшникового, та скорочення віку плодотворного осіменіння на 1,43 міс. У середньому на 1,81 міс. отримано скорочення плодотворного осіменіння телиць на раціонах з ТЕП-мікс у порівнянні з використанням раціонів з соєвим шротом. Застосування добавки КЕБ дозволило отримати середньодобові прирості за весь період вирощування на 11,21 \% більші у порівнянні використанням соняшникового шроту та на 6,22 \% у порівнянні з використанням соєвого шроту, знизити вік першого осіменіння на 0,65 і 0,29 місяців відповідно та скоротити вік плодотворного запліднення на 1,62 та 2,0 місяці відповідно.

Ключові слова: ремонтні телиці, енерго-протеїнові добавки, захищений протеїн, приріст, запліднення

DOI: https://doi.org/10.32845/bsnau.lvst.2020.1.12

В останні роки науковцями країн з розвиненим скотарством та України проводяться дослідження 3 удосконалення протеїнового живлення великої рогатої худоби. Це пов'язано, в першу чергу, з тим, що з ростом чисельності населення на планеті стрімко ростуть і потреби у продовольстві - хлібі, молоці, м'ясі та ін. Відповідно зростатиме потреба в зерні, як джерелі білкового та енергетичного корму для сільськогосподарських тварин. У таких обставинах зростає необхідність у розробці способів підвищення ефективності використання кормового білка та енергії в організмі жуйних тварин. Нормування раціонів годівлі великої рогатої худоби тільки за вмістом сирого протеїну, без урахування його розщеплюваності, призводить

до перевитрати кормового білка і, як наслідок, до порушення обміну речовин, утворенню надлишкового аміаку, який не йде на синтез білка, а виводиться з організму з сечею, хвороб тварин, зниженню продуктивності, Збільшенню собівартості продукції.

При направленому вирощуванні ремонтного молодняку та реалізації його генетичного потенціалу обов'язково необхідно враховувати той факт, що за рахунок кормів основного раціону забезпечується не більше половини потреби в синтезі білка та амінокислотах. Тому цей дефіцит необхідно покривати за рахунок введення концентратів. Проте, дуже часто в господарствах використовують дешеві білкові добавки з високим вмістом 
розщеплюваного протеїну. В останні роки в Україні почалися дослідження зі створення кормових продуктів, що містять захищений від розщеплення в рубці білок. Це дозволяє сорормувати додаткове джерело амінокислот, які всмоктуються в кишечнику, що $€$ хорошим засобом підвищення продуктивності тварин.

Вирощування молодняку великої рогатої худоби - це комплекс прийомів годівлі та утримання зростаючих телят, що сприяють розвитку у них особливостей, які визначають подальше племінне і господарське використання. Воно має бути цілеспрямованим, економічним, таким, що враховує біологічні особливості зростання і розвитку, формування міцної конституції, відповідного екстер'єру та інтер'єру, добрий розвиток органів травлення, становлення відтворювальної функції і довголітнє використання тварин [1].

Головна вимога до направленого інтенсивного вирощування ремонтних теличок для високопродуктивного стада корів - забезпечити оптимальний рівень і біологічну повноцінність їх годівлі, які гарантують досягнення живої маси при осіменінні 380-400 кг та 500-550 кг при розтеленні [2-4].

Особлива роль у живленні жуйних тварин належить протеїну [5]. У більшості сучасних систем протеїнового живлення при визначенні потреби тварин у ньому виходять не $з$ вмісту сирого та перетравного протеїну в раціоні, а 3 кількості протеїну, який розщеплюється в тонкому кишківнику і визначається як сума розщеплюваного і нерозщеплюваного в рубці. Новий підхід до забезпечення протеїнового живлення високопродуктивних тварин базується на забезпеченні організму тварин за рахунок легкорозчинних азотних сполук протеїну корму і небілкових джерел азоту, які синтезуються під час протеолізу білку мікроорганізмів і білку корму [2, 6-8].

Розщеплюваний у рубці протеїн $€$ джерелом азоту для мікроорганізмів, які використовують його для синтезу амінокислот і власного білка, а після розщеплення в тонкому кишечнику забезпечує від 50-90 \% потреби корів у амінокислотах [9].

у багатьох економічно розвинених країнах проводяться дослідження щодо вирішення проблеми дефіциту кормового білка, спрямовані, в першу чергу, на раціональне використання повноцінних кормів і біологічно активних добавок і створення кормових продуктів, що містять захищений від розщеплення в передшлунках білок, який здатний залишитися в нерозщепленому вигляді після проходження рубця і добре перетравним в шлунку і кишечнику корови. Така конструкція добавок дозволила ссрормувати додаткове джерело амінокислот, які всмоктуються в кишечнику, що стало хорошим засобом підвищення продуктивності тварин [2, 6, 10-14].

Метою наших досліджень було визначити ефективність використання енерго-протеїнових добавок ТЕП-мікс і КЕБ з захищеним від розщеплення в рубці протеїном на 62 - 65\% при вирощуванні ремонтних телиць 3 після молочного періоду до запліднення у порівнянні 3 традиційними білковими добавками (соняшниковий та соєвий шрот).

Кормові добавки ТЕП-мікс і КЕБ розроблені спільно співробітниками Інституту тваринництва НААН та ТОВ «Арніка ФІД» (м. Глобине Полтавської області).

Для виконання поставленої мети визначені наступні завдання:

- визначити хімічний склад та поживність кормів;

- встановити фрактичне споживання кормів;

- розробити повноцінні раціони годівлі з включенням енерго-протеїнових добавок с захищеним протеїном;

- встановити вплив розроблених добавок на ріст та розвиток ремонтних телиць.

Лабораторні дослідження по вивченню хімічного складу кормів, КЕБ, ТЕП-мікс і їх компонентів - на базі лабораторії якості кормів і продукції тваринного походження Інституту тваринництва НААН.

Науково-господарські дослідження 3 вивчення ефрективності використання КЕБ і ТЕП-мікс в раціонах ремонтних телиць на базі ДП ДГ «Гонтарівка» IT НААН співробітниками відділу годівлі сільськогосподарських тварин і кормовиробництва Інституту тваринництва НААН.

Матеріали та методи досліджень. В умовах племінного господарства ДП ДГ «Гонтарівка» Вовчанського району Харківської області було проведено науковогосподарський дослід 3 вивчення ефективності використання різних видів білкових кормових добавок в раціонах ремонтних телиць з 6-ти місячного віку до плідного осіменіння. Для цього були сформовані 4 групи аналогів по 12 голів в кожній, відібраних за принципом аналогів 3 урахуванням дати народження та живої маси, за наступною схемою (табл. 1).

Таблиця 1

Схема досліду

\begin{tabular}{|c|c|l|}
\hline Група & Голів & \multicolumn{1}{c|}{ Схема годівлі } \\
\hline 1 & 12 & Основний раціон + комбікорм з ТЕП-мікс \\
\hline 2 & 12 & Основний раціон + комбікорм з КЕБ \\
\hline 3 & 12 & Основний раціон + комбікорм з соняшниковим шротом \\
\hline 4 & 12 & Основний раціон + комбікорм з соєвим шротом \\
\hline
\end{tabular}

У процесі проведення досліду враховувалися наступні фактори:

- фактичний хімічний склад та поживність кормів (визначеними за загальноприйнятими методиками);

- фактичне споживання кормів шляхом проведення контрольних годівель кожні 10 днів впродовж двох суміжних діб в середньому по групі за визначення різниці між заданою кількістю кормів та їх залишків;

- показники живої маси (шляхом проведення контрольних зважувань кожні 30 днів);

- показники відтворювальної здатності телиць термін першого приходу в охоту, першого осіменіння, запліднення (шляхом підрахунку числа днів від народження до події).

- статистична обробка отриманих даних проводилась біометричними методами за [15] 3 визначенням рівня вірогідності.

Тривалість дослідження склала 487 днів. 
Умови утримання та годівлі були ідентичними.

Основний раціон був однаковим для всіх груп. Склад комбікормів відрізнявся компонентами та їх кількістю, але в той же час був ідентичний за базовими якісними показниками. Кормові добавки вводились до складу комбікорму.

Раціони усіх піддослідних тварин були ізопротеїнові та ізоенергетичними, збалансованими за всіма лімітованими органічними та мінеральними поживними речовинами згідно діючих деталізованих норм годівлі [16], з урахуванням хімічного складу та поживної цінності кормів та корегувалися щомісячно.

Для визначення впливу кормових добавок на ріст піддослідних тварин проводились контрольні індивідуальні зважування на початку та вкінці досліду, а також щомісячно під час дослідження.

Вплив розроблених добавок з захищеним протеїном на статевий розвиток телиць визначали за даними першого приходу в охоту, дати першого осіменіння та запліднення, кількості осіменінь до запліднення.

Результати досліджень. Для визначення есрективності використання розроблених енергопротеїнових добавок з захищеним протеїном ТЕП-мікс і КЕБ, під час досліджень проводились щомісячно контрольні зважування піддослідних телиць.

Зоотехнічні результати дослідження

\begin{tabular}{|c|c|c|c|c|}
\hline \multirow{2}{*}{ Показники } & \multicolumn{4}{|c|}{ Група } \\
\cline { 2 - 5 } & $\begin{array}{c}1 \\
\text { (ТЕП-мікс) }\end{array}$ & $\begin{array}{c}2 \\
\text { (КЕБ) }\end{array}$ & $\begin{array}{c}3 \\
\text { (шрот соняшниковий) }\end{array}$ & $\begin{array}{c}4 \\
\text { (шрот соєвий) }\end{array}$ \\
\hline Тривалість досліду, днів & 487 & 487 & 487 & 487 \\
\hline Середня жива маса, кг: & & & $170,8 \pm 8,84$ & $172,0 \pm 5,34$ \\
\hline початок досліду & $171,9 \pm 6,49$ & $168,7 \pm 6,61$ & $463,5 \pm 8,93$ & $478,7 \pm 12,94$ \\
\hline кінець досліду & $478,2 \pm 13,48$ & $494,4 \pm 9,75$ & 292,9 & 306,7 \\
\hline Середній приріст 1 голови, кг & 306,2 & 325,8 & 601 & 630 \\
\hline Середньодобовий приріст, г & 629 & 669 & & 6 \\
\hline
\end{tabular}

У результаті проведених досліджень було встановлено, що за 487 днів досліду середньодобові прирости телиць виявилися найвищим (669 г) в групі, що отримувала КЕБ. На 39 г (6,22 \%) вони був вищий $(\mathrm{P}>0.95)$, ніж у телиць, що отримували соєвий шрот, на 40 г (6,39 \%), ніж у телиць, що отримували ТЭП-мікс і на 68 г (11,21\%), ніж у телиць, що отримували шрот соняшниковий.

Також під час проведення дослідження проводили спостереження за статевим розвитком тварин. Так, прояв статевої охоти спостерігався у віці 11 місяців в усіх групах телиць.

Вік першого осіменіння телиць в групі 3 соняшниковим шротом склав 14,33 місяця, в групі зі соєвим шротом - 13,97 місяців, в групі з КЕБ - 13,68 місяців, в групі з ТЕП-мікс - 14,45 місяців. Середній вік першого осіменіння, з урахуванням вагових кондицій, у телиць всіх 4 груп склав в середньому - 434 дні або 14,2 місяця.

У той же час з плідним осіменінням картина дещо змінилася. Так, телиці другої групи, що отримувала в раціоні КЕБ, були запліднені в середньому у віці 16,7 місяців. Приблизно у такому ж віці (16,9 міс.) були запліднені тварини, що отримували в раціоні ТЕП-мікс. Середній вік запліднення телиць третьої та четвертої груп - 18,3 та 18,7 місяців відповідно.

Висновки. 1. Доведено позитивний вплив використання розроблених енерго-протеїнових добавок 3 захищеним від розщеплення в рубці протеїном ТЕП-мікс на $65,25 \%$ і КЕБ на $62,0 \%$ в годівлі ремонтних телиць 3 післямолочного періоду до статевої зрілості та запліднення.

2. Введення до складу раціону ремонтного молодняку молочного напрямку продуктивності добавки ТЕП-мікс дозволило підвищити середньодобові прирості за весь період вирощування на $4,53 \%$ у порівнянні 3 використанням шроту соняшникового, скоротити вік плодотворного осіменіння на 1,43 міс. (проти соняшникового шроту) - 1,81 міс. (проти соєвого шроту).

3. Введення до складу раціону ремонтного молодняку молочного напрямку продуктивності добавок КЕБ дозволило підвищити середньодобові прирості за весь період вирощування на $11,21 \%$ у порівнянні 3 соняшниковим шротом та на 6,22 \% у порівнянні з соєвим шротом, покращити вік першого осіменіння 0,65 і 0,29 місяців відповідно та скоротити вік плодотворного осіменіння на 1,62 та 2,0 місяці відповідно. 


\section{Список використаної літератури:}

1. Александров С. Н., Подобед Л. И., Косова Т. И., Дудинский В. Л. Теория и практика прибыльного производства молока. Киев : ПолиграфИнко, 2011. 173с.

2. Теорія і практика нормованої годівлі великої рогатої худоби; за ред. В. М. Кандиби, І. І. Ібатулліна, В. І. Костенка. Житомир: Рута, 2012. 860 с.

3. Подобед Л.И. Корма и кормление высокопродуктивного молочного скот. Днепропетровск : Арт-Пресс, 2012. 416

C.

4. Богданов Г. О. Норми, орієнтовні раціони та практичні поради з годівлі великої рогатої худоби ; за ред. І І І. Ібатулліна, В. І. Костенка. Житомир : ПП «Рута», 2013. 516 с.

5. Трисвятский Л. А. Соя : польза и проблемы. Зерновые культуры. 1995. № 1. С. 4-9.

6. Nutrient Requirements of Dairy Cattle : $7^{\text {th }}$ Rev. Ed. / National Research Council. Washington, D.C.: National Academy Press, 2001. 382 P.

7. Афранасьев В., Остриков А. Производство протеиновых концентратов на основе зернобобовых культур. Комбикорма. 2015. № 5.C. 30-36.

8. Bach A., Calsamiglia S., Stern M. D. Nitrogen metabolism in the rumen. J. Dairy Sci. 2005. Vol. 88. P. 9-21.

9. Калашников А. П., Клейменов Н. И., Баканов В. Н. и др. Нормы и рационы кормления сельскохозяйственных животных. Москва : Агропромиздат, 1985. 352 с.

10. Захарова А. Сухая барда в кормлении коров. Приусадебное хозяйство. 2010. № 7. С. 85.

11. Кальницкий Б. Д., Материкин А. М., Заболотнов Л. А., Харитонов Е.Л., Фицев А. И., Медведев И. К. Протеиновое питание молочных коров : рек. Боровск, 1998. 26 с.

12. Matthe A., Lebzien P., Flachowsky G. On the relevance of bypass-starch for the glucose supply of highyielding dairy cows. Übers. Tierernähr. 2000. № 28. P. 1-64.

13. Nocek J. E., Tamminga S. Site of digestion of starch in the gastrointestinal tract of dairy cows and its effect on milk yield and composition. J. Dairy Sci. 1991. N. 74. P.3598-3629.

14. Xu S., Harrison J.H., Chalupa W., Sniffen C., Julien W., Sato H., Fujieda T., Watanabe K., Ueda T., Suzuki H. The Effect of Ruminal Bypass Lysine and Methionine on Milk Yield and Composition of Lactating Cows. J. Dairy Sci. 1998. Vol. 81 P.1062-1077.

15. Плохинский Н. А. Руководство по биометрии для зоотехников. Москва : Колос, 1969. 155 с.

16. Норми і раціони повноцінної годівлі високопродуктивної великої рогатої худоби:довідник-посібник ; за ред. Г.О. Богданов, В.М.Кандиби. Київ : Аграр. наука, 2012. 296 с.

\section{References:}

1. Aleksandrov S. N., Podobed, L. I., Kosova, T.I., Dudinskij, V. L., 2011. Teorija i praktika pribyl'nogo proizvodstva moloka [Theory and practice of profitable milk production]. Kiev : Poligraflnko.

2. Kandyba, V. M., Ibatullin, I. I., Kostenko, V. I., et al., 2012. Teoriia i praktyka normovanoi hodivli velykoi rohatoi khudoby [The theory and practice of normalized feeding of cattle]. Zhitomir: «Ruta».

3. Podobed, L. I., 2012. Korma i kormlenie vy'sokoproduktivnogo molochnogo skota [Feed and feeding of highperformance dairy cattle]. Dnepropetrovsk : Art - Press.

4. Bogdanov, G. O., 2013. Normy, orientovni ratsiony ta praktychni porady z hodivli velykoi rohatoi khudoby [Standards, indicative diets and practical tips for feeding cattle]. Zhitomir : PP «Ruta».

5. Trisvjatskij, L. A., 1995. Soja: pol'za i problemy. Zernovye kul'tury, 1, 4-9.

6. National Research Council., 2001. Nutrient Requirements of Dairy Cattle (7th Rev. Ed.) Washington, D.C.: National Academy Press. 382.

7. Afanas'ev, V., Ostrikov. A., 2015. Proizvodstvo proteinovyh koncentratov na osnove zernobobovyh kul'tur. Kombikorma, 5, 30-36.

8. Bach, A., Calsamiglia, S. and Stern, M. D., 2005. Nitrogen metabolism in the rumen. J. DairySci., 88, 9-21

9. Kalashnikov, A. P., Klejmenov N. I., et al., 1985. Normy i raciony kormlenija sel'skohozjajstvennyh zhivotnyh: Spravochnoe posobie [Norms and diets of feeding farm animals: a reference guide]. M.: Agropromizdat, 352.

10. Zaharova, A., 2010. Suhaja barda v kormlenii korov. Priusadebnoe hozjajstvo, 7, pp. 85.

11. Kal'nickij, B. D., Materikin, A. M., Zabolotnov, L. A., Haritonov, E. L., Ficev, A. I. and Medvedev, I. K., 1998. Proteinovoe pitanie molochnyh korov: Rekomendacii po normirovaniju [Protein nutrition for dairy cows: recommendations for rationing], Borovsk, 26.

12. Matthe, A., Lebzien, P. and Flachowsky, G., 2000. On the relevance of bypass-starch for the glucose supply of highyielding dairy cows. Übers. Tierernähr, no. 28, pp. 1-64.

13. Nocek, J. E., and Tamminga, S., 1991. Site of digestion of starch in the gastrointestinal tract of dairy cows and its effect on milk yield and composition. J. Dairy Sci, 74, pp. 3598-3629.

14. Xu, S., Harrison, J. H., Chalupa, W., Sniffen, C., Julien, W., Sato, H., Fujieda, T., Watanabe, K., Ueda, T. and Suzuki, H., 1998.The Effect of Ruminal Bypass Lysine and Methionine on Milk Yield and Composition of Lactating Cows. J. Dairy Sci. 81, pp. 1062-1077. Kolos, 155

15. Plohinskij, N. A., 1969. Rukovodstvo po biometrii dlja zootehnikov[Biometrics Guide for Livestock Specialists], M.:

16. Bogdanov, G. O., et al., 2013. Normy, oriientovni ratsiony ta praktychni porady z hodivli velykoi rohatoi khudoby 
[Standards, indicative diets and practical tips for feeding cattle]. Zhitomir : PP «Ruta».

Sedyuk Igor Yevgenyevich, PhD of Agricultural Sciences, Institute of Animal Husbandry NAASU

Zolotarev Andrey Petrovich, Researcher, Institute of Animal Husbandry NAAS

Zolotareva Svetlana Anatoliyivna, PhD of Agricultural Sciences Kharkiv National Agrarian University

Mashkin Mykola Ivanovych, Ph.D. of Agricultural Sciences, Professor, Sumy National Agrarian University

Efficiency of application energy-protein supplements with the protected protein at growing of repair heifers

The article presents the results of a study to determine the effectiveness of the use in the feeding of heifers developed energy-protein supplements protected from cleavage in the rumen protein by 62 - $65 \%$ when growing repair heifers from after the milk period to fertilization compared with traditional protein additives - sunflower and soy with the grooves. Feed additives of TEP-mix and KEB were developed jointly by the staff of the Institute of animal husbandry of NAAS and LLC "Arnika FID" (Globine, Poltava region). Scientific and economic research was carried out on the basis of the State Enterprise "Gontarivka" of the Institute of Animal Production of the NAAS. In an experiment lasting 487 days in four groups of young animals of dairy direction with a productivity of 12 heads in each studied the actual consumption of feed, determined the dynamics of live weight, average daily growth, the term of the first arrival in hunting, the first insemination and fertilization. The positive influence of the use of developed energy-protein supplements with the protected protein TEP-mix and KEB in feeding of heifers from the postdairy period is proved. The introduction into the diet of the young growth of milk production efficiency of the TEP-mix additives allowed to obtain average daily increments for the whole period of cultivation by $4.53 \%$ more compared to the use in sunflower meal rations and reduction of the fruitful insemination age by 1.43 months. On average, 1.81 months. reduction of fruitful insemination of heifers in rations with TEP-mix compared with the use of rations with soybean meal. The use of the KEB supplement allowed for an average daily increase of $11.21 \%$ over the sunflower meal and $6.22 \%$ over the use of soybean meal, to reduce the age of first insemination by 0.65 and 0.29 months, respectively, and reduce the fertility age by 1.62 and 2.0 months, respectively.

Key words: repair heifers, energy-protein supplements, protected protein, gain, fertilization

Дата надходження до редакції: 14.01.2020 p. 